\title{
THE SPATIAL PATTERN OF BROWNFIELDS AND CHARACTERISTICS OF REDEVELOPED SITES IN THE OSTRAVA METROPOLITAN AREA (CZECH REPUBLIC)
}

\author{
Jiří NOVOSÁK, Oldřich HÁJEK, Jana NEKOLOVÁ, Pavel BEDNÁŘ
}

\begin{abstract}
Differences between brownfields and redeveloped sites in the Ostrava metropolitan area are subject to analysis in this paper. Environmental burden and former functional use were identified as statistically significant characteristics of such differences. In addition, relations between selected attributes of brownfields and redeveloped sites were analyzed using the "if-then" decision rules of the rough set method. In this way, the research demonstrated the significance of spatial aspects and identified two fundamental types of brownfields in the model area. The first type is represented by agricultural brownfields in the hinterland zone, that are characterized by a complicated ownership structure. Brownfields of the second type are located particularly in the inner city morphogenetic zone, and are characterized by potential problems with environmental burden. In this context, brownfields and redeveloped sites differ respectively in the combination of these characteristics.
\end{abstract}

\section{Shrnutí}

\section{Prostorový vzorec a charakteristiky brownfields a nově využitých lokalit v Ostravské metropolitní oblasti (Česká republika)}

Cílem článku je analyzovat rozdíly mezi brownfields a nově využitými lokalitami v ostravské metropolitní oblasti. Ekologická zátěž a bývalé funkční využití byly v tomto ohledu identifikovány jako statisticky významné charakteristiky. Současně jsou na bázi využití „když - pak“ rozhodovacích pravidel metody rough množin hodnoceny relace mezi vybranými atributy brownfields a nově využitými lokalitami. $V$ tomto ohledu výzkum potvrdil významnost prostorových aspektů a identifikoval dva základní typy brownfields $v$ modelové oblasti. První typ je reprezentován zemědělskými brownfields v zázemí modelové oblasti, které jsou charakteristické komplikovanou vlastnickou strukturou. Brownfields druhého typu jsou lokalizovány převážně v morfogenetické zóně vnitřního města a jsou charakteristické potenciálními problémy sekologickými zátěžemi. Kombinace uvedených charakteristik nám umožňuje odlišit brownfields a nově využité lokality.

Keywords: brownfields, redeveloped sites, rough-set method, Ostrava metropolitan area, Czech Republic

\section{Introduction}

Sustainable development is regarded as a prominent concept in modern society, posing the challenge of balancing economic, social and environmental goals. A number of conflict issues exist (see e.g. Conroy and Berke, 2004), however, including soil consumption. From the sustainability viewpoint, it is highly desirable to reduce soil consumption as much as possible. Thus, it is not surprising that the redevelopment of brownfields is fully in accord with the sustainable development concept (Hemphill, Berry, McGreal, 2004). Nevertheless, there are several barriers to brownfield redevelopment, including the fundamental characteristics of brownfields. Spatially, the issue of brownfields is discussed in various contexts. First, brownfields are firmly embedded in research focused on the decline and regeneration of old industrial regions in Europe and North America (e.g. Florida, 1995). Second, brownfields in metropolitan areas are subject to research, considering specifics of morphogenetic zones on the one hand, and development problems of compact and dispersed cities on the other (e.g. Sýkorová, 2007; Kunc, Klusáček, Martinát, 2011). Third, the developmental potential of brownfields 
in rural and peripheral regions has been evaluated (see e.g. Svobodová, Věžník, 2009; Vaishar, Jakešová, Náplavová, 2011; Klusáček, Krejčí, Kunc, Martinát, Nováková, 2011). Altogether, the spatial dimension is an important element in brownfield research.

These issues create the cornerstones of this article. Our focus is on the spatial analysis of the fundamental characteristics of brownfields, a common theme in the scholarly literature (see e.g. Kunc and Tonev, 2008). However, the characteristics of brownfields are traditionally evaluated in isolation, not considering the relations between brownfields on the one hand and redeveloped sites on the other. Thus, the goal of this research is to analyze the differences between brownfields and redeveloped sites, emphasising their spatial location in morphogenetic zones of the Ostrava metropolitan area. The article is structured as follows: the next section provides theoretical underpinnings of our research; the third section sketches out our methodology; the fourth section presents the main empirical findings and these are further discussed in the fifth section, followed by our conclusions.

\section{Literature review}

Brownfield redevelopment has been a subject of research from several viewpoints. The first area of interest, relevant for our article, concerns barriers of brownfield redevelopment, which include the characteristics of brownfields. There are several attributes analyzed in the scholarly literature.

The potential for brownfield redevelopment is in many cases reduced by the location of brownfields in inner cities (Doetsch, Rüpke, 1998). Such a location tends to be connected with a limited space for firm expansion and with complicated transport accessibility (e.g. KollSchretzenmayr, 2000 for case studies on this issue). This situation reduces the redevelopment potential of brownfields because transport infrastructure is an important location factor in the decision-making process of developers (see e.g. Holl, 2004). Moreover, it is noteworthy that city centres and suburban areas are regarded as morphogenetic zones with the most evident changes in the functional-spatial structure of post-socialist cities (Sýkora, 2003). Thus, the potential of brownfield redevelopment in inner cities is further affected.

Potential brownfield redevelopment may be further lowered by an intricate ownership structure. In this regard, Adams, Disberry, Hutchison, Munjoma (2001) underline the owners' undue notion of brownfield value on the one hand and at their unwillingness to sell or rent brownfield sites for various reasons on the other. Similarly, Koll-Schretzenmayr (2000) identified intricate ownership structure as one of the main barriers to brownfield redevelopment. The brownfield legacy is reflected not only in an intricate ownership structure but also in the uncertainty of environmental burden. Consequently, financial and time costs of brownfield redevelopment projects increase (Nijkamp, van den Burch, Vindingi, 2002).

There are two areas of research where characteristics of brownfields play an important role. The first area is focused on the spatial analysis of brownfields; for example, Kunc, Tonev (2008) chose the city of Brno for their analysis. The spatial dimension of their analysis was based on morphogenetic zones of the city and they showed the importance of the inner city for the location of brownfields. Sýkorová (2007) who focused her analysis on the City of Prague, employed the same analysis, identifying the inner city and suburban zones as the most problematic ones when considering the location of brownfields. In other studies, Vojvodíková, Potužník, Bürgermeisterová (2011) dealt with brownfields at a municipal level, while Svobodová, Vě̌ník (2008) carried out research at a regional level. These research projects have two aspects in common: first, various attributes of brownfields were quantified (including former functional uses, environmental burden, transport accessibility, or ownership structure); subsequently, the authors suggested a form of brownfield classification.

The second area of research concerns the evaluation of brownfield redevelopment potential. Traditionally, simple multi-criteria methods are applied and attributes of brownfields play the role of criteria. Their different importance is estimated by weights and some form of aggregation of the criteria provides the value of brownfield redevelopment potential. Such a model was suggested for example by Doetsch, Rüpke (1998), and in a slightly adapted version replicated by Rydvalová and Žižka (2006). Similarly, Vojvodíková (2004) developed an evaluation model based on multi-criteria methods.

The above-mentioned areas are very important for brownfield redevelopment research but spatial analyses of brownfields are traditionally realized in isolation, not considering their broader relations to redeveloped sites. In this respect, the brownfield-greenfield debate is more common (see e.g. De Sousa, 2006).

\section{Methodology}

To meet the goal of this article, a complex methodological approach was applied: for further details, see Novosák (2009). In this section, we sketch out the most important aspects of the methodology. 


\subsection{Determination of brownfields and redeveloped sites}

The first aspect of the methodology is related to the question of how to define the key terms of brownfield (see Alker, Joy, Roberts, Smith, 2000 for a detailed review of definitions) and of a redeveloped site. Various attributes of brownfields play a role when defining the term, but the requirement of unused or underused site is the most controversial because of its subjective nature (see e.g. Yount, 2003).

In this article, brownfields and redeveloped sites are defined using four characteristics. Two of them are common for both types of sites - the requirement of area size larger than one hectare on the one hand, and of a limited set of functional uses on the other. This set includes agricultural, mining, industrial, transportation, military and other non-residential functional uses except dumps and selected public service facilities. It is noteworthy that our methodology is focused on rather large non-residential brownfields a quite common approach in brownfield assessment (see e.g. Kunc and Tonev, 2008 or Sýkorová, 2007).

The third characteristic employed for the identification of brownfields is the degree of their functional use in the period 2008-2009. In this regard, we first compiled a database of sites larger than one hectare, which were used for any of the above-mentioned functional uses in the early 1990s. For this purpose, we used cartographic and other archival sources of information. Subsequently, we identified brownfields based on their ownership structure and physical deterioration. There was a requirement that a total ownership share of entities active on the site was below 50\% of its area. Ownership structure data was compiled from cadastre.

Thefourth characteristicemployed for theidentification of redeveloped sites is the change in economic activities between the early 1990s and the period 2008-2009. In this regard, we first compiled a database of sites larger than one hectare, which were used for any of the above-mentioned functional uses in 2008-2009. Subsequently, we identified entities active on the site in the early 1990s using cartographic and other archival sources of information. Subsequently, the position of these entities in 2008-2009 was evaluated. A site was understood as redeveloped if the entities active thereon in the early 1990 s were not dominant employers on the site in 2008-2009.

Finally, two methodological notes have to be added. First, the sample of brownfields and redeveloped sites was compiled using the authors' own methodology that included analyses of cartographic and archival sources and field mapping. In this regard, our sample was different from the official databases such as the brownfield database of Ostrava City (e.g. Vojvodíková et al., 2011). Second, in the definition of redeveloped sites we emphasized the change of dominant employers. There could have been various periods when the redeveloped sites were not used, so that redeveloped sites in our definition are not necessarily redeveloped brownfields in the traditional way of thinking - longterm abandoned sites.

\subsection{Model area delimitation}

The second aspect of the methodology concerns the question how to define the Ostrava metropolitan area, the model area of our analysis. This task was resolved on the basis of close functional links between the Ostrava City and surrounding municipalities. Thus, requirements on daily employment commuting to Ostrava City, on administrative links with Ostrava City, and on urban mass public transport connection with Ostrava City were imposed (see Novosák, 2009 for details). On this basis, the administrative area of Ostrava City (including five specific zones: compact inner city, dispersed inner city, zone of housing estates, zone of transition, and suburban zone) and thirty one municipalities in its hinterland (constituting the zone of surrounding municipalities) formed our model area (see Fig. 1).

\subsection{Additional data sources}

The third aspect of the methodology is the selection of attributes for the further analysis of differences between brownfields and redeveloped sites. In this regard, we respected the most important attributes identified in our literature review: Tab. 1 summarizes these attributes and their possible values. Note that the analysis is based on categorical values of the attributes.

The data matrix represents the fourth aspect of the methodology. Thus, brownfields and redeveloped sites in the model area were identified as rows of the data matrix. Subsequently, values of the analyzed attributes were added for all identified brownfields and redeveloped sites, represented as columns.

\subsection{Methods of statistical analysis}

Finally, the fifth aspect of the methodology is related to the evaluation of the data matrix. Two methodological approaches are used: (1) traditional methods of descriptive and inferential statistics - since the evaluated attributes are categorical in nature, we use the analysis of frequencies (Pearson's Chi-square and Cramer's V statistics) in our decisions on differences between brownfields and redeveloped sites, differences are related both to the number and total area of brownfields and redeveloped sites; and (2) broader relations between the evaluated attributes on the one hand and brownfields and 
redeveloped sites on the other, were analyzed by the rough-set method. This method provides a robust theoretical framework for the interpretation of information of quantitative and qualitative nature (see e.g. Pawlak, Slowinski, 1994; Bruinsma, Nijkamp, Vreeker, 2002). In this article, the method was used to generate the so-called "if-then" decision rules. The "if" part contains conditions - a combination of the values of attributes. The "then" part is a decision conditioned by the combination. Thus, we dealt with the question what combinations of the values of attributes classify sites as brownfields.

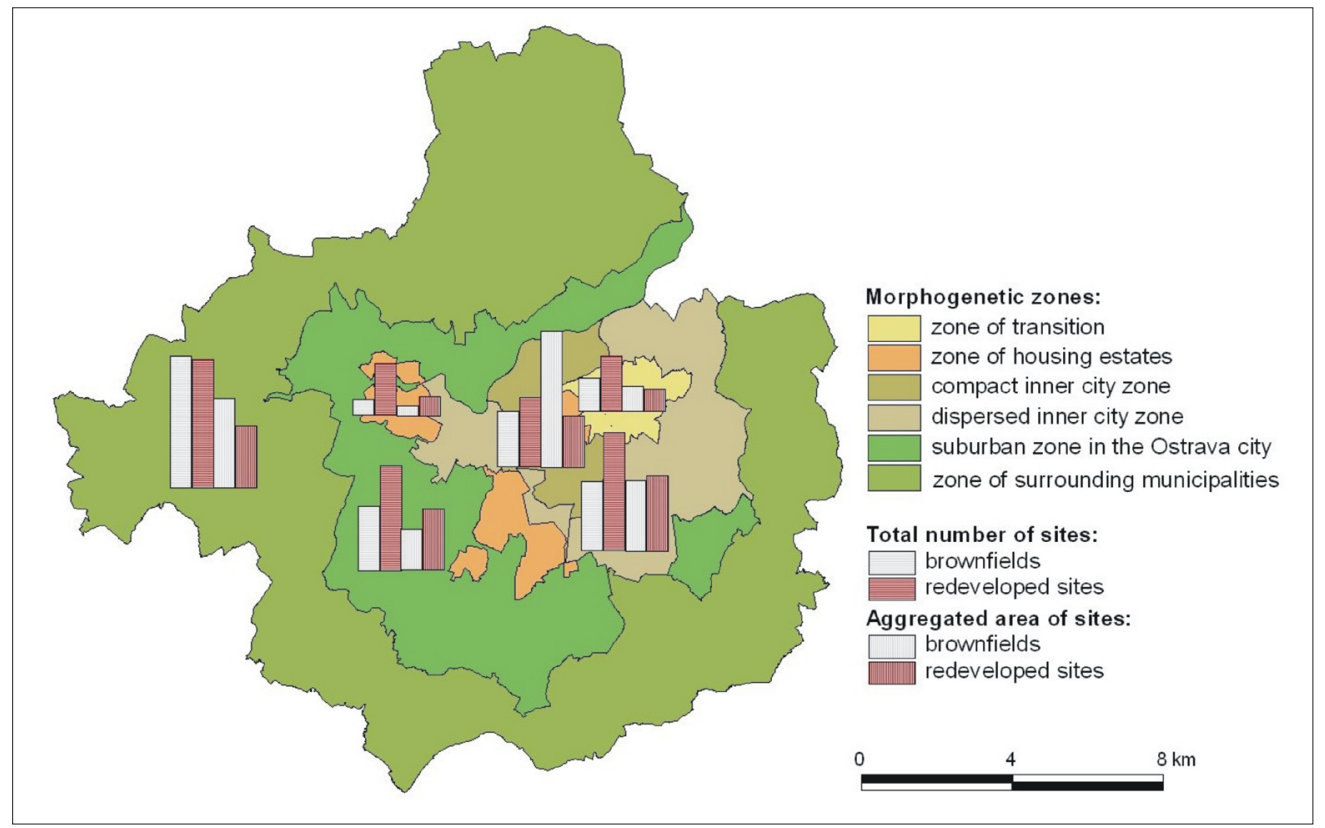

Fig. 1: Brownfields in morphogenetic zones of the Ostrava metropolitan area

Source: Authors' elaboration (based on Novosák, 2009)

\begin{tabular}{|l|l|}
\hline \multicolumn{1}{|c|}{ Attribute } & \multicolumn{1}{c|}{ Values } \\
\hline Location in morphogenetic zones of the model area (see Fig. 1) & $\begin{array}{l}\text { Zone of transition } \\
\text { Zone of housing estates } \\
\text { Compact inner city zone } \\
\text { Dispersed inner city zone } \\
\text { Suburban zone in Ostrava city } \\
\text { Zone of surrounding municipalities }\end{array}$ \\
\hline $\begin{array}{l}\text { Transport accessibility (Source: authors' calculation of distances based on vector } \\
\text { maps of communication - available from <http://geoportal.cenia.cz }>\text { ) }\end{array}$ & $\begin{array}{l}\text { Very good - direct connection to expressways } \\
\text { Good - direct connection to first class road } \\
\text { Bad - direct connection to second or third class road } \\
\text { Very bad - other cases }\end{array}$ \\
\hline $\begin{array}{l}\text { Ownership structure derived from the number of owners and their shares in } \\
\text { total site area (Source: authors' compilation based on data from the cadastre - } \\
\text { available from <http://nahlizenidokn.cuzk.cz }>\text { ) }\end{array}$ & $\begin{array}{l}\text { Not complicated } \\
\text { Complicated } \\
\text { Very complicated }\end{array}$ \\
\hline $\begin{array}{l}\text { Threat of environmental burden derived from the former functional use and } \\
\text { existence of environmental burden in official databases (Source: authors' com- } \\
\text { pilation based on various cartographic and archival resources for particular sites } \\
\text { and system of contaminated sites, available from <http://sekm.cenia.cz>) }\end{array}$ & $\begin{array}{l}\text { Low } \\
\text { Medium } \\
\text { High } \\
\text { Extremely high }\end{array}$ \\
\hline $\begin{array}{l}\text { Former functional use (Source: authors' compilation based on various cartogra- } \\
\text { phic and archival resources for particular sites) }\end{array}$ & $\begin{array}{l}\text { Agriculture } \\
\text { Mining } \\
\text { Manufacturing and construction } \\
\text { Services }\end{array}$ \\
\hline $\begin{array}{l}\text { Area (Source: authors' compilation based on data from the cadastre - available } \\
\text { from <http://nahlizenidokn.cuzk.cz }>\text { ) }\end{array}$ & $\begin{array}{l}\text { Small - less than } 5 \text { ha } \\
\text { Medium - 5-10 ha } \\
\text { Large - more than 10 ha }\end{array}$ \\
\hline
\end{tabular}

Tab. 1: Evaluated attributes of brownfields and redeveloped sites

Source: adapted from Novosák (2009) 


\section{Empirical results - characteristics of brownfields and redeveloped sites}

Our analysis is based on a sample of 181 sites. These include 74 brownfields with a total area of 699 hectares and 107 redeveloped sites with a total area of 529 hectares. Are there significant differences between brownfields and redeveloped sites, considering their location in the morphogenetic zones of the model area? Tab. 2 shows the results. The number and the total area of brownfields are relatively high in the inner city zones and suburban zones. However, the highest ratio between the area of brownfields and redeveloped sites is observed in the compact inner city zone. The ratio is relatively higher also for the zone of transition and the zone of surrounding municipalities. Corresponding figures for other morphogenetic zones are lower. On the other hand, there are no statistically significant differences between the numbers of brownfields and redeveloped sites if their location in the morphogenetic zones of the model area is analyzed.
Taking a closer look at the other characteristics of brownfields and redeveloped sites, Tab. 3 shows the results for the transport accessibility attribute. Two findings are noteworthy: first, there are brownfields with various qualities of transport accessibility. The location of brownfields close to the highway network may be an important development factor for relatively large brownfields in the model area. Second, there are not statistically significant differences between the numbers of brownfields and redeveloped sites if the quality of their transport accessibility is analyzed.

Tab. 4 differentiates brownfields and redeveloped sites according to their ownership structure. It is shown that a very complicated ownership structure is more typical for relatively large brownfields in the model area. Thus, the good quality of their transport accessibility is compensated by a fragmented ownership structure. However, there are not statistically significant differences between the numbers of brownfields and redeveloped sites if the ownership structure attribute is analyzed.

\begin{tabular}{|l|c|c|c|c|}
\hline \multirow{2}{*}{\multicolumn{1}{c|}{ Morphogenetic zones }} & \multicolumn{2}{c|}{ Brownfields } & \multicolumn{2}{c|}{ Redeveloped sites } \\
\cline { 2 - 5 } & Number & Area (ha) & Number & Area (ha) \\
\hline Zone of transition & 6 & 38.9 & 11 & 33.0 \\
\hline Zone of housing estates & 2 & 9.9 & 8 & 98.2 \\
\hline Compact inner city zone & 11 & 270.9 & 14 & 143.8 \\
\hline Dispersed inner city zone & 14 & 134.4 & 25 & 113.3 \\
\hline Suburban zone in Ostrava City & 13 & 71.2 & 22 & 115.4 \\
\hline Zone of surrounding municipalities & 28 & 173.5 & 27 & 95.1 \\
\hline
\end{tabular}

Tab. 2: Brownfields and redeveloped sites in the model area-location in morphogenetic zones

Source: Authors' calculations (based on Novosák, 2009)

\begin{tabular}{|l|c|c|c|c|}
\hline \multirow{2}{*}{\multicolumn{1}{|c|}{ Transport accessibility }} & \multicolumn{2}{c|}{ Brownfields } & \multicolumn{2}{c|}{ Redeveloped sites } \\
\cline { 2 - 5 } & Number & Area (ha) & Number & Area (ha) \\
\hline Very good & 12 & 299.6 & 10 & 60.0 \\
\hline Good & 12 & 111.1 & 28 & 146.3 \\
\hline Poor & 34 & 198.3 & 54 & 279.0 \\
\hline Very poor & 16 & 89.8 & 15 & 43.5 \\
\hline
\end{tabular}

Tab. 3: Brownfields and redeveloped sites in the model area-transport accessibility Source: Authors' calculations (based on Novosák, 2009)

\begin{tabular}{|l|c|c|c|c|}
\hline \multirow{2}{*}{\multicolumn{1}{|c|}{ Ownership structure }} & \multicolumn{2}{c|}{ Brownfields } & \multicolumn{2}{c|}{ Redeveloped sites } \\
\cline { 2 - 5 } & Number & Area (ha) & Number & Area (ha) \\
\hline Not complicated & 30 & 173.7 & 51 & 182.1 \\
\hline Complicated & 26 & 161.7 & 41 & 216.0 \\
\hline Very complicated & 18 & 363.4 & 15 & 130.7 \\
\hline
\end{tabular}

Tab. 4: Brownfields and redeveloped sites in the model area-ownership structure

Source: Authors' calculations (based on Novosák, 2009) 
Environmental burden is regarded as an important barrier to brownfield redevelopment. Tab. 5 shows differences between brownfields and redeveloped sites if the threat of environmental burden is considered. There is a relatively low threat of environmental burden for a high number of both brownfields and redeveloped sites. However, an extremely high threat of environmental burden is very typical for large brownfields in the model area. It is noteworthy that differences between brownfields and redeveloped sites according to the variable of environmental burden are statistically significant at the $1 \%$ level.

Former functional use is the last analyzed attribute of brownfields and redeveloped sites. Tab. 6 depicts the structures of brownfields and redeveloped sites according to their former functional use. Differences between brownfields and redeveloped sites are obvious. Agriculture and mining are typical for brownfields, while manufacturing and services characterize redeveloped sites. In addition, large brownfields were used as former mining and manufacturing sites. It is also worth mentioning that the differences between brownfields and redeveloped sites according to their former functional use are statistically significant at a $1 \%$ level of significance.

\section{Discussion - brownfields and redeveloped sites in broader relations}

The preceding discussion revealed the main differences between brownfields and redeveloped sites in the model area according to the five selected attributes. Our findings may be summarized as follows:

- The highest number of brownfields occurs in the morphogenetic zone of the surrounding municipalities. Moreover, a relatively high number of brownfields were used for agricultural production. Tab. 7 shows that agricultural brownfields are overrepresented in the morphogenetic zone of the surrounding municipalities. Thus, a relationship between these two variables may be expected in this respect.

- Large brownfields are located especially in the compact inner city zones. Moreover, large brownfields are characterized by good transport

\begin{tabular}{|l|c|c|c|c|}
\hline \multirow{2}{*}{ Threat of environmental burden } & \multicolumn{2}{|c|}{ Brownfields } & \multicolumn{2}{c|}{ Redeveloped sites } \\
\cline { 2 - 5 } & Number & Area (ha) & Number & Area (ha) \\
\hline Low & 31 & 136.7 & 53 & 208.1 \\
\hline Moderate & 14 & 122.0 & 31 & 152.5 \\
\hline High & 4 & 24.7 & 12 & 101.2 \\
\hline Extremely high & 25 & 415.4 & 11 & 67.0 \\
\hline
\end{tabular}

Tab. 5: Brownfields and redeveloped sites in the model area - threat of environmental burden Source: Authors' calculations (based on Novosák, 2009)

\begin{tabular}{|l|c|c|c|c|}
\hline \multirow{2}{*}{\multicolumn{1}{c|}{ Former functional use }} & \multicolumn{2}{c|}{ Brownfields } & \multicolumn{2}{c|}{ Redeveloped sites } \\
\cline { 2 - 5 } & Number & Area (ha) & Number & Area (ha) \\
\hline Agriculture & 26 & 112.1 & 21 & 47.7 \\
\hline Mining & 21 & 203.2 & 5 & 23.7 \\
\hline Manufacturing and construction & 13 & 330.3 & 39 & 267.4 \\
\hline Services & 14 & 53.2 & 42 & 190.0 \\
\hline
\end{tabular}

Tab. 6: Brownfields and redeveloped sites in the model area-former functional use Source: Authors' calculations (based on Novosák, 2009)

\begin{tabular}{|l|c|c|c|c|}
\hline \multirow{2}{*}{ Former functional use } & \multicolumn{2}{|c|}{ Surrounding municipalities } & \multicolumn{2}{c|}{ Other zones } \\
\cline { 2 - 5 } & Brownfields & Redeveloped Sites & Brownfields & Redeveloped Sites \\
\hline Agriculture & $43 \%$ & $26 \%$ & $13 \%$ & $19 \%$ \\
\hline Mining & $15 \%$ & $4 \%$ & $65 \%$ & $15 \%$ \\
\hline Manufacturing and construction & $0 \%$ & $21 \%$ & $25 \%$ & $54 \%$ \\
\hline Services & $7 \%$ & $5 \%$ & $18 \%$ & $70 \%$ \\
\hline
\end{tabular}

Tab. 7: Brownfields and redeveloped sites in the model area-former functional use structure related to the location in morphogenetic zones. Source: Authors' calculations (based on Novosák, 2009) 
accessibility, complicated ownership structure, high threat of environmental burden, and former mining or manufacturing functional use. It is remarkable that there are eleven brownfields in the compact inner city zone: six of them have the above-mentioned characteristics.

Based on this argument, it seems evident that there are two fundamental types of brownfields in the model area. Their location in morphogenetic zones may be regarded as an important differentiating factor is this sense. To verify these assumptions we decided to employ two methodological approaches. First, we statistically tested the significance of differences between the brownfields and the redeveloped sites in only two morphogenetic zones - the city and its hinterland. Second, we constructed the most common combinations of the values of attributes using the rough-set method.

Tab. 8 summarizes the results of the first methodological approach, and the findings confirm the relevance of the above-mentioned assumptions. Thus, former functional use is statistically significant for both morphogenetic zones. Mining as a former functional use is typical for brownfields in the city zone, while agriculture is typical for brownfields in the hinterland zone. In addition, the threat of environmental burden represents a more important barrier for brownfield redevelopment in the city zone. Transport accessibility and ownership structure are not statistically significant attributes, but note that the former seems to play a more important role in differentiating brownfields and redeveloped sites in the city zone, while the latter plays the same role in the hinterland zone.

In the second methodological approach - the rough-set method - six attributes of brownfields and redeveloped sites were defined as independent variables. These included the five attributes analyzed above and the total area of sites as a sixth independent variable. The dependent variable provided the choice between the brownfield category on the one hand and the redeveloped site category on the other. Applying the rough-set method, the "if - then" decision rules were generated. Subsequently, we observed what combinations of independent variable values classified sites as brownfields.

Tab. 9 shows the results. The highest number of brownfields is classified if they meet the conditions of extremely high threats of environmental burden, complicated ownership structure, and mining as their former functional use (see DR1). Just mining as a former functional use seems to be the most frequent differentiating factor between brownfields and redeveloped sites in the model area (see DR1, DR4, D6, DR7, and DR9). The development potential of mining brownfields may be further worsened by extremely high threats of environmental burden (see DR1, DR9), by large area (see DR4), or poor transport accessibility (see DR7, DR9) of brownfields. Extremely high threats of environmental burden and relatively large area seem to be an important brownfield redevelopment barrier more generally (see DR8, DR10). Evaluation of the transport accessibility attribute is not so straightforward (see DR6). Altogether, these findings are fully in accord with the characteristics of brownfields located in the city zone as defined in Tab. 8 .

There are three other decision rules in Tab. 9 DR2, DR3, and DR5. Two of them, DR2 and DR3, describe a similar situation. Sites located in the zone of surrounding municipalities with a very complicated ownership structure are usually classified as brownfields (see DR2). The condition of low threat of environmental burden in DR2 closely relates to the former agricultural functional use of brownfields (see DR3). In addition, close links between relatively larger agricultural brownfields (see DR3) and complicated ownership structure (see D2) may be expected. It is worth mentioning the statistically significant difference between brownfields and redeveloped site in the hinterland zone, if one considers their former functional use (see Tab. 8). Agricultural brownfields are the most common type in this regard: the findings are fully in line with the characteristics of brownfields located in the hinterland zone as defined in Tab. 8.

\begin{tabular}{|l|c|c|c|c|}
\hline \multirow{2}{*}{\multicolumn{1}{|c|}{ Attributes }} & \multicolumn{2}{c|}{ City } & \multicolumn{2}{c|}{ Hinterland } \\
\cline { 2 - 5 } & Pearson's Chi-square & Cramer's V & Pearson's Chi-square & Cramer's V \\
\hline Transport accessibility & 0.072 & 0.277 & 0.560 & 0.151 \\
\hline Ownership structure & 0.877 & 0.054 & 0.070 & 0.243 \\
\hline Environmental burden & $0.000^{*}$ & 0.522 & 0.070 & 0.280 \\
\hline Former functional use & $0.000^{*}$ & 0.511 & $0.002^{*}$ & 0.401 \\
\hline
\end{tabular}

Tab. 8: Statistical significance of differences between brownfields and redeveloped sites - selected attributes; asymptotic significance of Pearson's Chi-square; * Statistically significant at $1 \%$ level of significance

Source: Authors' calculations (based on Novosák, 2009) 


\begin{tabular}{|l|l|c|}
\hline Rule & \multicolumn{1}{|c|}{ Combination of independent variable values } & Number \\
\hline DR1 & OS = complicated AND TEB = extremely high AND FFU = mining & 8 \\
\hline DR2 & LMZ = zone of surrounding municipalities AND OS = very complicated AND TEB = low & 7 \\
\hline DR3 & FFU = agriculture AND A = medium & 6 \\
\hline DR4 & FFU = mining AND A = large & 6 \\
\hline DR5* & OS = complicated AND TEB = low AND TA = bad AND FFU = agriculture & 5 \\
\hline DR6 & TA = very good AND FFU = mining & 5 \\
\hline DR7 & TA = very poor AND FFU = mining & 5 \\
\hline DR8 & TA = very good AND TEB = extremely high AND A = large & 5 \\
\hline DR9 & TA = poor AND TEB = extremely high AND FFU = mining & 4 \\
\hline DR10 & LMZ = Zone of transition AND TEB = extremely high & 6 \\
\hline
\end{tabular}

Tab. 9: The number of brownfields classified by "if - then" decision rules; a review of decision rules with more than three classified brownfields

Note: LMZ - location in morphogenetic zones; TA - transport accessibility; OS - ownership structure; TEB - threat of environmental burden; FFU - former functional use; $A$ - area

* This decision rule classifies six brownfields and seven redeveloped sites. It is not possible to differentiate these sites. Source: Authors' calculations (based on Novosák, 2009)

Altogether, our assumptions about the existence of two types of brownfields in the Ostrava metropolitan area were confirmed by both methods. There are relevant implications from these findings, which may be used especially in the strategic planning of brownfield redevelopment. Generally, specifics of particular brownfield sites should be considered in this regard.

First, there is a very limited redevelopment potential of large mining brownfields in the inner city. A complicated ownership structure and a high threat of environmental burden may further worsen the situation (see DR1). Even very good transport accessibility is not a trigger for redevelopment processes (see DR6). The "if - then" decision rules show no success story of redevelopment of these sites for any functional use of interest in the model area. However, some additional aspects must be added. The abandoned sites of this kind represent cheap properties for small and medium-size enterprises. The former Jan Šverma mine may be regarded as an example. Then, a question is whether it is desirable to think always of large-scale brownfield redevelopment projects. Moreover, some mining sites in the model area have been redeveloped for functional uses, which are not assessed in this paper (e.g. conversion for cultural purposes). Then again, our findings show that flexible territorial planning and support for non-manufacturing redevelopment projects should be considered.

Second, there is a very limited redevelopment potential of agricultural brownfields in relatively small municipalities in the hinterland of the Ostrava metropolitan area. Two aspects seem to be relevant in this respect when analyzing the decision rules in Tab. 9. The first aspect relates to bad transport accessibility (see DR5). However, a complicated ownership structure seems to be much more relevant (see DR2, DR5) because of several redeveloped sites in the hinterland of the Ostrava metropolitan area, which were previously used for manufacturing or services. In our arguments, agricultural brownfields are a legacy of the restitution processes and a consolidation of their ownership structure is necessary to plan for the redevelopment of these sites.

\section{Conclusion}

Brownfield redevelopment is an important research area because of its close links to the sustainable development concept. Several research themes are considered in this regard, but empirical knowledge of the differences between brownfields and redeveloped sites is rather scarce. This article contributes to the current state of knowledge by analyzing the differences between brownfields and redeveloped sites in the model area of the Ostrava metropolitan area. Spatial aspects are emphasised at the level of morphogenetic zones.

The compact inner city zone of the model area shows the highest ratio between the area of brownfields and redeveloped sites. Thus, the problem of brownfields may be perceived as very relevant in this morphogenetic zone. In addition, the highest number of brownfields is identified in the zone of surrounding municipalities. Thus, our analysis confirms the conclusions formulated by Sýkorová (2007) that the inner city of Prague and its suburban areas are most affected by the location of brownfields.

Some attributes are identified as statistically significant in explaining differences between brownfields and redeveloped sites. These include the 
threat of environmental burden and former functional use. However, the spatial aspect must be considered as well because there are two fundamental types of brownfields in the model area. The first type includes agricultural brownfields in the hinterland zone of the model area, characterized by a complicated ownership structure. The second type of brownfields is located especially in the inner city zone and is characterized by potential problems with environmental burden. Several abandoned coal mines belong to the second type of brownfields.

Altogether, our findings confirm some more general considerations on the dynamics of changes in the internal spatial structure of metropolitan regions and on the low development potential of brownfields in a peripheral hinterland. On the other hand, there are some specifics related to the Ostrava metropolitan area, especially the legacy of abandoned coal mines. The findings from our research are rather pessimistic considering their future. Moreover, there are over 600 hectares of manufacturing sites in the compact inner city morphogenetic zone, still used by the same economic entity as in the early 1990s. This area may be understood as a dormant brownfield threat for the Ostrava metropolitan region.

Our findings show that it is necessary to consider spatial location and other characteristics of brownfields in their redevelopment process. There is not a "one-case-fits-all" solution. In this respect, the methodological approach applied in this article may provide worthwhile information on brownfield development potential.

\section{Acknowledgement}

The authors are thankful to the Internal Grant Agency of Tomas Bata University in Zlin for the grant No. IGA/FaME/2012009.

\section{References:}

ADAMS, D., DISBERRY, A., HUTCHISON, N., MUNJOMA, T. (2001): Ownership constraints to brownfield redevelopment. Environment and Planning A, Vol. 33, No. 3, p. 453-477.

ALKER, S., JOY, V., ROBERTS, P., SMITH, N. (2000): The definition of brownfield. Journal of Environmental Planning and Management, Vol. 43, No. 1, p. 49-69.

BRUINSMA, F., NIJKAMP, P., VREEKER, R. (2002): A comparative industrial profile analysis of urban regions in Western Europe: an application of rough set classification. Tijdschrift voor Economische en Sociale Geografie, Vol. 93, No. 4, p. 454-463.

CONROY, M. M., BERKE, P. R. (2004): What makes a good sustainable development plan? An analysis of factors that influence principles of sustainable development. Environment and Planning A, Vol. 36, No. 8, p. 1381-1396.

DE SOUSA, C. (2006): Unearthing the benefits of brownfield to green space projects: an examination of project use and quality of life impacts. Local Environment, Vol. 11, No. 5, p. 577-600.

DOETSCH, P., RÜPKE, A. (1998): Revitalisierung von Altstandorten versus Inanspruchnahme von Naturflächen. Berlin, Umweltbundesamt, $589 \mathrm{pp}$.

FLORIDA, R. (1995): The industrial transformation of the Great Lakes Region. In Cooke, P.: The rise of the Rustbelt. London, UCL Press, p. 162-176.

HEMPHILL, L., BERRY, J., MCGREAL, S. (2004): An indicator-based approach to measuring sustainable urban regeneration performance: part 1, conceptual foundations and methodological framework. Urban Studies, Vol. 41, No. 4, p. $725-756$.

HOLL, A. (2004): Manufacturing location and impacts of road transport infrastructure: empirical evidence from Spain. Regional Science and Urban Economics, Vol. 34, No. 3, p. 341-363.

KLUSÁČEK, P., KREJČÍ, T., KUNC, J., MARTINÁT, S., NOVÁKOVÁ, E. (2011): The post-industrial landscape in relation to local self-government in the Czech Republic. Moravian Geographical Reports, Vol. 19, No. 4, p. 18-28.

KOLL-SCHRETZENMAYR, M. (2000): Strategien zur Umnutzung von Industrie und Gewerbebrachen. Zürich, Hochschullverlag, 269 pp.

KUNC, J., KLUSÁČEK, P., MARTINÁT, S. (2011): Percepce a lokalizace urbánních brownfields: podobnosti a rozdíly na př́kladu Brna a Ostravy. Urbanismus a územní rozvoj, Vol. 14, No. 1, p. 13-17.

KUNC, J., TONEV, P. (2008): Funkční a prostorová diferenciace brownfields - příklad města Brna. Regionální studia, Vol. 1, No. 1 , p. 30-37.

NIJKAMP, P., BURCH, VAN DEN, J., VINDINGI, G. (2002): A comparative institutional evaluation of public-private partnership in Dutch urban land-use and revitalisation projects. Urban Studies, Vol. 39, No. 10, p. 1865-1880.

NOVOSÁK, J. (2009): Prostorová analýza brownfields na Ostravsku. Ostrava, Ostravská univerzita v Ostravě, 133 pp. 
PAWLAK, Z., SLOWINSKI, R. (1994): Rough set approach to multi-attribute decision analysis. European Journal of Operational Research, Vol. 72, No. 3, p. 443-459.

RYDVALOVÁ, P., ŽIŽKA, M. (2006): Ekonomické souvislosti revitalizace brownfields. Politická ekonomie, Vol. 54, No. 5, p. $632-645$.

SVOBODOVÁ, H., VĚŽNÍK, A. (2009): To the problems of agricultural brownfields in the Czech Republic - case study of the Vysočina region. Agricultural Economics - Czech, Vol. 55, No. 11, p. 550-556.

SÝKORA, L. (2003): Suburbanizace a její společenské důsledky. Sociologický časopis, Vol. 39, No. 2, p. 217-233.

SÝKOROVÁ, I. (2007): Pražská brownfields: př́ležitost i hrozba pro rozvoj metropole. Geografie, Vol. 112, No. 4, p. $250-265$.

VAISHAR, A., JAKEŠOVÁ, L., NÁPLAVOVÁ, M. (2011): Current problems in the South-Moravian rural landscape. European Countryside, Vol. 3, No. 4, p. 265-281.

VOJVODÍKOVÁ, B. (2004): Některé možnosti využití opuštěných pozemků po důlních podnicích. Urbanismus a územní rozvoj, Vol. 7, No. 5, p. 12-16.

VOJVODÍKOVÁ, B., POTUŽNÍK, M., BÜRGERMEISTEROVÁ, R. (2011): The database on brownfields in Ostrava (Czech Republic): some approaches to categorization. Moravian Geographical Reports, Vol. 19, No. 4, p. 50-60.

YOUNT, K. R. (2003): What are brownfields? Finding a conceptual definition. Environmental Practice, Vol. 6, No. 1, p. $25-33$.

\section{Authors' addresses:}

Mgr. Jiří NOVOSÁK, Ph.D., e-mail: novosak@fame.utb.cz RNDr. Oldřich HÁJEK, Ph.D., e-mail: hajek@fame.utb.cz Ing. Jana NEKOLOVÁ, , e-mail: j.nekolova@seznam.cz RNDr. Pavel BEDNÁŘ, Ph.D., e-mail: bednar@fame.utb.cz Department of Regional Development, Public Administration and Law Faculty of Management and Economy, Tomas Bata University in Zlín Mostní 5139, 76001 Zlín, Czech Republic

Initial submission 15 December 2012, final acceptance 30 May 2013

Please cite this article as:

NOVOSÁK, J., HÁJEK, O., NEKOLOVÁ, J., BEDNÁŘ, P. (2013): Spatial Pattern of Brownfields and Characteristics of Redeveloped Sites in the Ostrava Metropolitan Area (Czech Republic). ). Moravian Geographical Reports, Vol. 21, No. 2, p. 36-45. 